\title{
Paleoparasitology of Merovingian Corpses Buried in Stone Sarcophagi in the Saint-Martin-au-Val Church (Chartres, France)
}

\author{
Benjamin Dufour ${ }^{1, *}$, Emilie Portat ${ }^{2,3}$, Bruno Bazin ${ }^{2,4}$, Matthieu Le Bailly,* \\ ${ }^{1}$ University of Bourgogne Franche-Comte, CNRS UMR 6249 Chrono-environment, 16 Route de Gray, 25030 Besancon cedex, France; ${ }^{2}$ Direction \\ de l'archéologie, Chartres Métropole, Place des Halles, 28019 Chartres cedex, France; ${ }^{3} \mathrm{CNRS}$ UMR 7041 Archéologies et Sciences de l'Antiquité, \\ Maison Archéologie \& Ethnologie, René-Ginouvès, 21 Allée de l'Université, 92000 Nanterre, France; ${ }^{4} C N R S$ UMR 8546 Archéologie \& Philologie \\ d'Orient et d'Occident, École normale supérieure, 45 rue d'Ulm, 75230 Paris cedex 05, France
}

\begin{abstract}
Paleoparasitological analysis was carried on 4 Merovingian skeletons, dated from the late-5th to the late-9th centuries, and recovered in the church of Saint-Martin-au-Val in Chartres (Center region, France). The corpses were buried in stone sarcophagi, which were still sealed at the time of excavation. Parasite marker extraction was conducted on sediment samples taken from the abdominal and pelvic regions, but also on samples taken from under the head and the feet as control samples. Microscopic observation revealed the presence of 3 gastrointestinal parasites, namely the roundworm (Ascaris lumbricoides), the whipworm (Trichuris trichiura) and the fish tapeworm (genus Diphyllobothrium). This analysis contributes to a better knowledge of the health status and the lifestyle of ancient medieval populations during the Merovingian period, for which very few paleoparasitological data were available, up until now. It demonstrates the presence of the fish tapeworm for the first time during this period.
\end{abstract}

Key words: Paleoparasitology, gastrointestinal parasite, sarcophagi, Merovingian

Paleoparasitology is the study of ancient parasites from paleontological and archaeological sites. It aims to detect traces of parasites in ancient human and animal populations, and to study the evolution of parasitism over time and space [1]. It developed at the beginning of the 20th century with studies carried out on ancient human remains. Sir Marc A. Ruffer [2] was the first to retrieve eggs of a gastrointestinal parasite in 2 Egyptian mummies, followed, some decades later, by Szidat [3], who found evidence of parasites on the Karwinden Man, a 5th century bog mummy from Poland. Some years later, methods diversified when Taylor [4] performed paleoparasitological analysis on sediment samples taken from the latrines of an archaeological site in medieval London. With this analysis, Taylor showed the interest of studying such samples, and began what now represents the main type of analysis in current paleoparasitological research.

- Received 30 August 2019, revised 13 September 2019, accepted 15 September 2019. *Corresponding authors (benjamin.dufour@univ-fcomte.fr; matthieu.lebailly@univ-fcomte.fr)

(c) 2019, Korean Society for Parasitology and Tropical Medicine

This is an Open Access article distributed under the terms of the Creative Commons Attribution Non-Commercial License (http://creativecommons.org/licenses/by-nc/4.0) which permits unrestricted non-commercial use, distribution, and reproduction in any medium, provided the original work is properly cited.
Since then, most of the studies in Western Europe have focused on hollowed structures, such as latrines or pits, in which the filling can derive from various sources, ranging from human to several combinations of animals. Curiously, in current European research, fewer funerary sites and samples from human burials are studied. For example, out of the Roman period sites studied for ancient parasites since 1944, only 20\% (20 sites out of 99) correspond to funerary contexts with samples taken from human skeletons. However, it is now crucial to work on samples taken directly from material associated with humans as this gives us access to paleoparasitological information directly connected to human beings, which is not necessarily the case with hollowed structures. Here, we present the study of 4 stone sarcophagi from the Merovingian period dated to the late-5th to late-9th centuries, discovered during the excavations of a church in the center of France. This work aims to provide information on parasite diversity, the health status and lifestyle of the studied individuals, as well as funerary practices during the Merovingian period.

The church of Saint-Martin-au-Val (hereafter SMV) is localized in Chartres, in the Center region in France (Fig. 1). It presents several phases of construction extending from the 12th to 


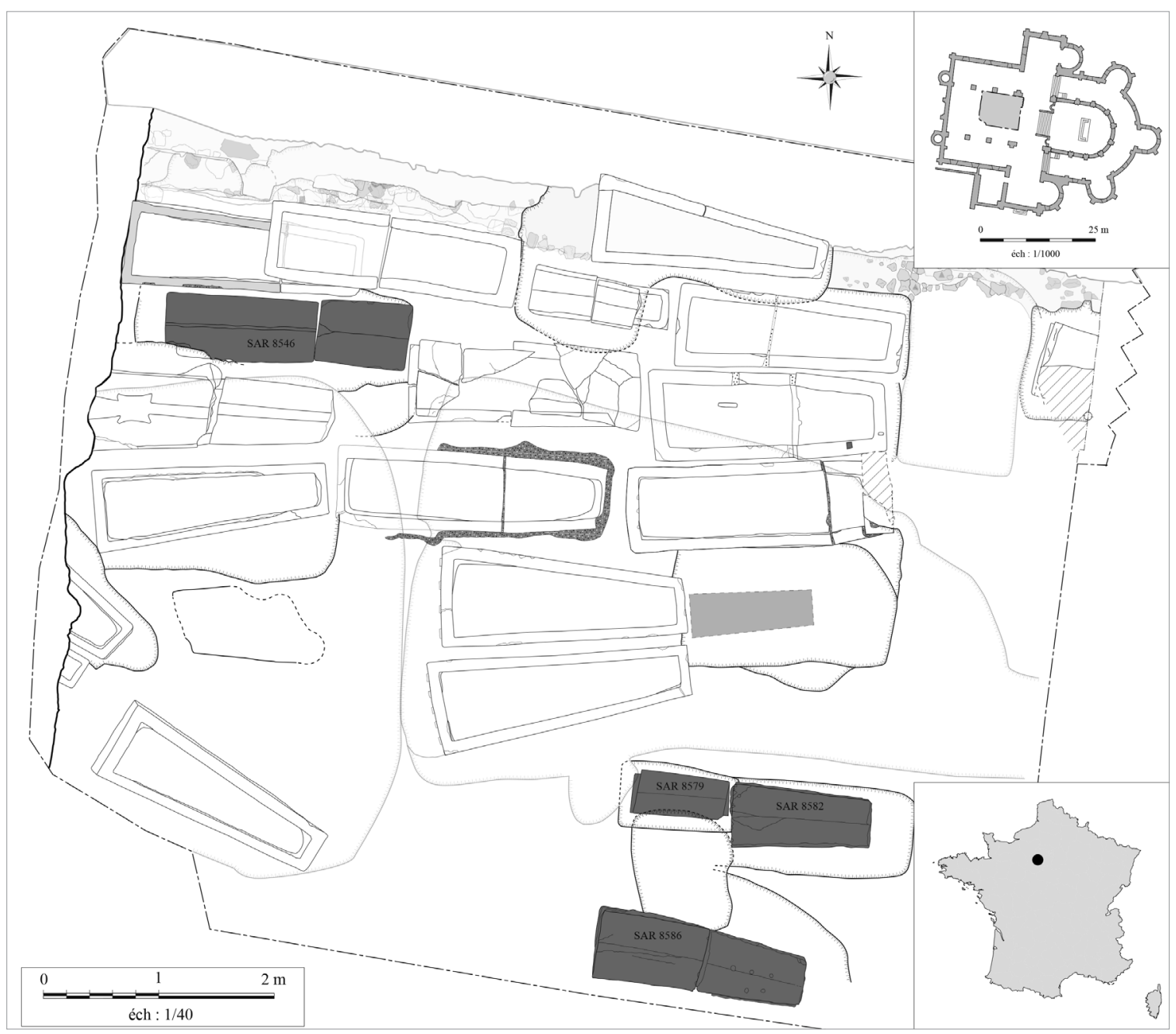

Fig. 1. Location of the site of Chartres in France and plan of the excavation of the church (plan: Direction de l'archéologie - Chartres Métropole modified by B. Dufour).

the 19th centuries. The excavation inside the nave revealed Merovingian levels with masonry elements that could belong to a Merovingian building, constructed between the late-5th and the early-6th centuries, prior to the construction of the current church. Many limestone sarcophagi from this Merovingian period were discovered (around 20 up until now) and correspond to individuals from a high-ranking social class. Among them, 4 were still sealed with mortar at the time of discovery (Fig. 1). Two monolithic sarcophagi contained the remains of 2 children. The first, of undetermined gender, was aged between 5 and 8 months (SAR 8579, SEP 8584, dated probably between the late-5th and the mid-6th centuries). The second, of undetermined gender, was aged between 1 year and 1.5 years (SAR 8582, SEP 8672, dated between the late-5th and the mid-6th centuries) (Fig. 2A, B). The 2 other sarcophagi studied were bipartite and were connected by mortar. They contained adult remains. One contained the remains of a young adult female (SAR 8546, SEP 8624, dated between the mid-8th and the end of the 9th centuries). The second contained the remains of an aged male (SAR 8586, SEP 8677, dated between the end of the 5th to the mid-6th centuries) (Fig. 2C, D) [5-7].

The discovery of still sealed Merovingian sarcophagi is exceptional as they provide access to bodies that have not been disturbed since burial. This was confirmed, in particular, by the presence of preserved organic matter when the sarcophagi were opened. To better understand funerary practices during this period (treatment of the body, offerings, etc.), and provide information about individuals (paleopathologies, diet, etc.), pluridisciplinary research was conducted, including anthro- 

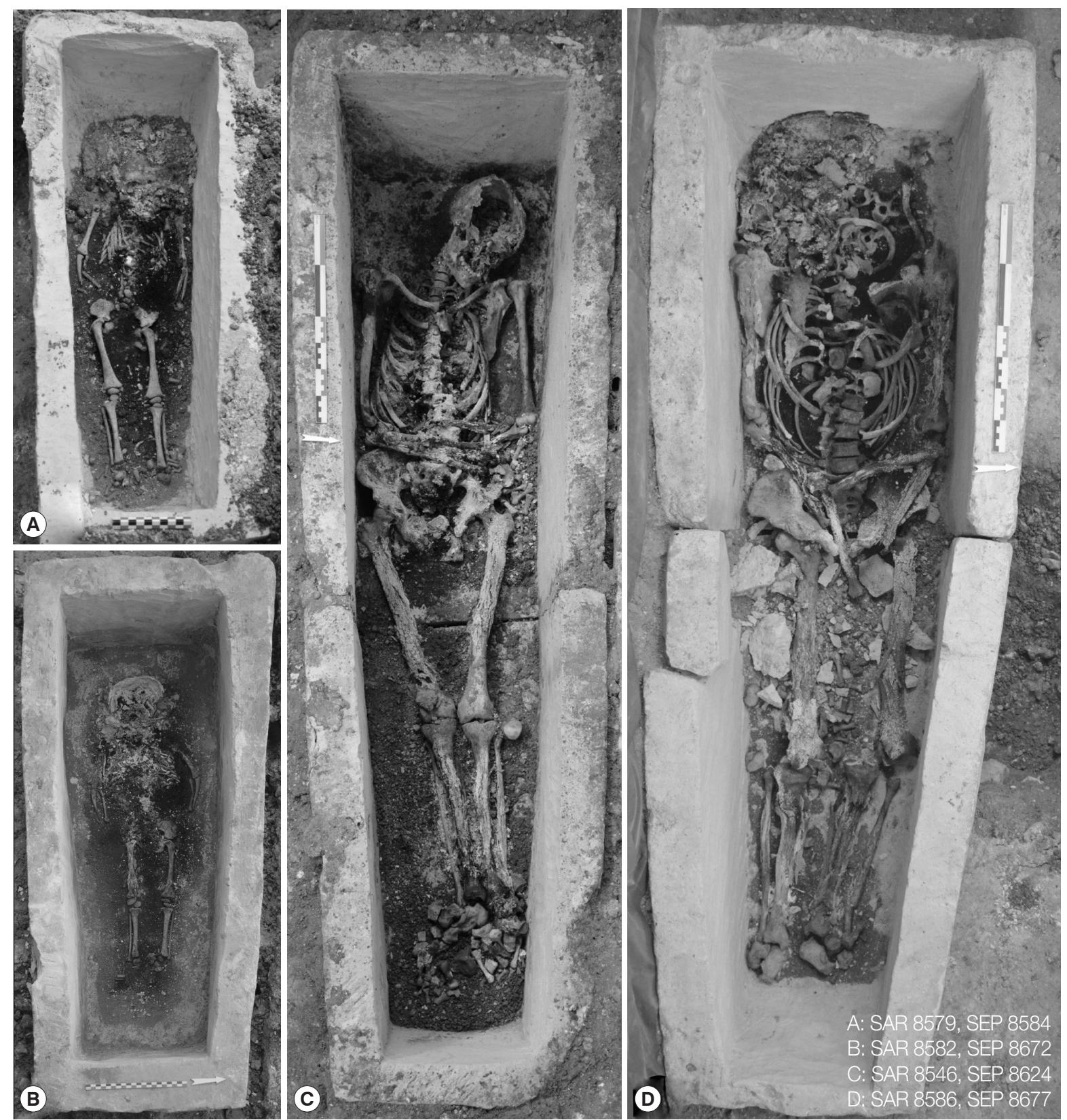

Fig. 2. Sarcophagi with the individuals (photos: Direction de l'archéologie - Chartres Métropole).

pology, palynology, entomology, chemical analyses, sedimentology and paleoparasitology. In paleoparasitology, this type of context is particularly interesting because few sarcophagi and sites from the Merovingian period have been studied. Moreover, this type of burial allows for the preservation of organic matter, unlike wooden coffins or shrouds. If no looting or damage to the structure occur throughout time, and if it remains sealed since burial, almost no outside elements contaminate the contents. As a consequence, the potentially ob- served parasites unquestionably belong to the individuals buried in the sarcophagi.

To our knowledge, only 2 stone sarcophagi have been analyzed in paleoparasitology up to now, both from the same Roman site of Jaunay-Clan, in France. In these burials, one of the 2 individuals tested positive to the human whipworm Trichuris trichiura [8].

The aim of our analysis was to retrieve potential preserved gastrointestinal parasite eggs using light microscopy. Fourteen 
Table 1. Description of the studied material and results (in number of eggs)

\begin{tabular}{|c|c|c|c|c|c|c|}
\hline Sarcophagus & Burial & Samples & Description & $\begin{array}{l}\text { Ascaris lumbricoides } \\
\text { Normal/decorticated }\end{array}$ & $\begin{array}{l}\text { Trichuris } \\
\text { (trichiura) }\end{array}$ & $\begin{array}{l}\text { Diphyllobothrium } \\
\text { sp. }\end{array}$ \\
\hline \multirow[t]{4}{*}{ SAR 8546} & Sep-24 & $\mathrm{P} 4$ & Under the head & $-/ 1$ & 1 & - \\
\hline & & P6 & Under the lower thorax & $-/ 1$ & - & - \\
\hline & & P16 & Between and under the coxal bones & $1 / 1$ & 1 & - \\
\hline & & $\mathrm{P} 20$ & Under and around the feet & $1 /-$ & - & - \\
\hline \multirow[t]{4}{*}{ SAR 8579} & Sep-84 & $\mathrm{P} 1$ & In the pelvis, between the coxal bones & $-/-$ & - & - \\
\hline & & P2 & In the abdominal cavity & $-/-$ & - & - \\
\hline & & P3 & Under the skull bones & $-/-$ & - & - \\
\hline & & P4 & Under the feet & $-/-$ & - & - \\
\hline \multirow[t]{3}{*}{ SAR 8582} & Sep-72 & P112 & Under the head & $-/-$ & - & - \\
\hline & & P119, P120, P127 & In the pelvis & $-/-$ & - & - \\
\hline & & $\mathrm{P} 116, \mathrm{P} 117, \mathrm{P} 140$ & In the abdomen & $-/-$ & - & - \\
\hline \multirow[t]{3}{*}{ SAR 8586} & Sep-77 & $\mathrm{P} 1, \mathrm{P} 2$ & Under the head & $-/-$ & 1 & 1 \\
\hline & & P7, P8, P9, P10 & In the abdomen & $-/-$ & - & - \\
\hline & & $\mathrm{P} 11, \mathrm{P} 12, \mathrm{P} 13$ & In the pelvis & $-/-$ & - & - \\
\hline
\end{tabular}
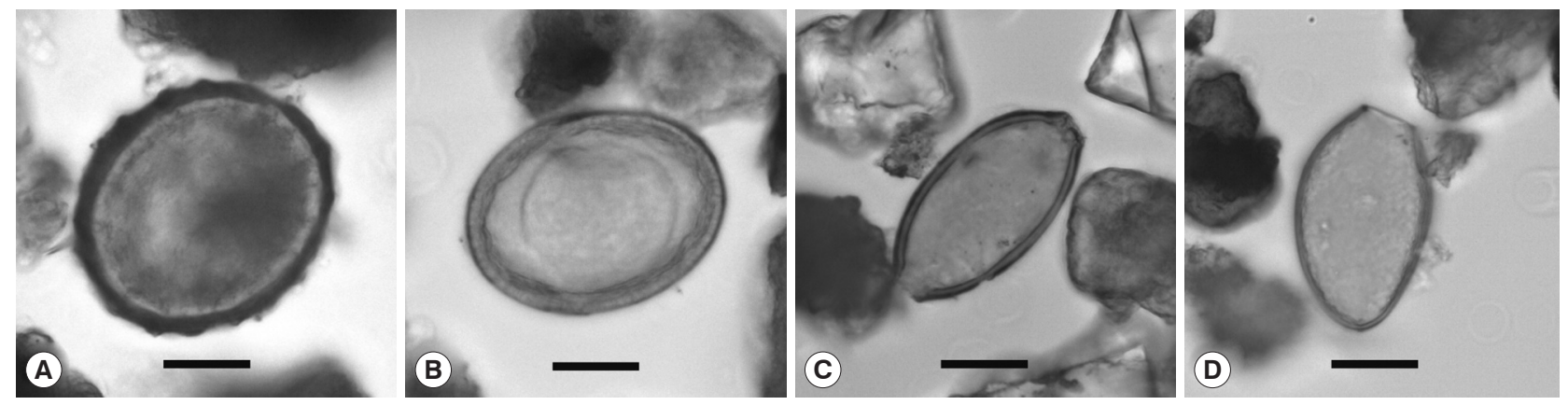

Fig. 3. Eggs observed in samples. (A) Ascaris lumbricoides; (B) Ascaris lumbricoides decorticated egg; (C) egg of Trichuris probably trichiura; (D) Diphyllobothrium sp. Scale bars $=20 \mu \mathrm{m}$ (photos: B. Dufour).

sediment samples were analyzed, taken from the abdominal and pelvic regions, and also from under the head and the feet as control samples. Table 1 summarizes the distribution of sampling on each corpse. The standard RHM protocol (Rehydration-Homogenization-Microsieving) used in the Besancon laboratory was applied [9]. Five grams of each sample were rehydrated for 10 days in a solution of $0.5 \%$ TSP and $5 \%$ glycerinated water. Several drops of $10 \%$ formalin solution were added to avoid fungal or algal development. The material was then crushed in a mortar. The suspension was treated in an ultrasonic device for $1 \mathrm{~min}(50 / 60 \mathrm{~Hz})$ and strained through $315,160,50$, and $25 \mu \mathrm{m}$ meshes under a constant flux of water. The eggs of parasites ranging in size from approximately 30 to $160 \mu \mathrm{m}$ [10] were concentrated in the 25 and $50 \mu \mathrm{m}$ sieves. The last 2 screenings were placed in $4 \mathrm{ml}$ tubes with water, and drops of $10 \%$ formalin solution were added to each tube. Finally, 4 to 6 slides $(22 \times 22 \mathrm{~mm})$ of $15 \mu$ of the sample were examined under an optical microscope (Olympus BX-
51). Parasite eggs were accurately counted and identified using recent parasitological literature.

Out of the 4 studied individuals, only the adult samples tested positive to the presence of gastrointestinal parasites. Two parasite taxa were identified in each adult burial (Table 1). All samples from the children yielded negative results.

In SEP 8624, 2 ovoid eggs with a thick mamillated shell were observed, measuring $64.0 \times 57.1 \mu \mathrm{m}$ for the first (sample P16) and $74.4 \times 49.5 \mu \mathrm{m}$ for the second (sample P20) (Fig. $3 \mathrm{~A})$. The biological origin of the sample, as well as the characteristics of the eggs, allowed us to identify them as the human large roundworm, Ascaris lumbricoides. In archaeological contexts, the taphonomic processes can produce "decorticated" eggs due to the loss of the outer mamillated eggshell. Three ovoid eggs corresponding to this decorticated morphotype were also identified in the burial. Their size varies between 60.6 and $64.5 \mu \mathrm{m}$ in length, and 44.2 and $46.1 \mu \mathrm{m}$ in width (Fig. 3B). The second parasite taxon retrieved in SEP 8624 
presents ovoid eggs with a smooth surface, characterized by 2 polar plugs giving them a characteristic lemon shape. The 2 recovered eggs were identified as belonging to the genus Trichuris. Considering the archaeological and sampling context, these 2 eggs probably correspond to the human species, $T$. trichiura. However, the eggs are slightly larger than the human species. The dimensions of the first egg are $60.4 \times 34.5 \mu \mathrm{m}$ (sample P4) and $60.7 \times 29.0 \mu \mathrm{m}$ (sample P16) for the second. The most frequently cited dimensions for human whipworm eggs T. trichiura are comprised between 50 and $58 \mu \mathrm{m}$ long, and 24 and $28 \mu \mathrm{m}$ wide [11]. This slight variation could be due to taphonomic processes, but the eggs may also belong to animal species, as their size potentially matches with $T$. suis, $T$. discolor, T. leporis and T. muris, parasites of pigs, herbivores, lagomorphs and rodents, respectively. However, it is not possible to be more precise, mainly because of the small number of remains observed.

In SEP 8677, a single egg of the genus Trichuris was also observed. Unlike the previous eggs, the size of the egg observed in this burial corresponds perfectly to the human whipworm, T. trichiura (Fig. 3C).

In burial SEP 8677, a second parasite taxon accompanied the whipworm. One single ovoid operculate, slightly asymmetrical egg was observed, with a smooth surface, and with a small knob opposite the operculum side. Egg size was $50.6 \mu \mathrm{m}$ long and $31.6 \mu \mathrm{m}$ wide (Fig. 3D). These characteristics correspond to the fish tapeworm genus Diphyllobothrium. The eggs of some species of this genus present ornamentation on the surface of the eggshell, and show a more or less marked punctuated appearance. During analyses, we only observed one egg with a smooth surface, which could correspond to species transmitted by freshwater fish, such as $D$. latum or $D$. dentriticum.

Owing to the ecology of parasites, their lifecycles and transmission routes, when parasite markers are retrieved in archaeological samples, paleoparasitology can answer different questions relating to the health status and lifestyle of ancient individuals and populations $[1,12]$. In the case of the individuals from SMV church, 3 gastrointestinal parasites were recovered, namely the human large roundworm, the human whipworm and the fish tapeworm. The first 2 parasites present the same direct lifecycle. Adult worms are localized in the host (human) intestines, reproduce, and infestation occurs by ingesting eggs polluting drinking water or food, or by accidental geophagy. These 2 parasitoses are related to a general hygiene problem, inadequate management of human or animal fecal waste (the passageways are not cleaned), or/and the use of fecal matter as a crop fertilizer. Human infestations with these parasites are usually asymptomatic, but in the case of massive loads, they can cause abdominal pain, diarrhea, nausea, vomiting. In case of roundworm disease, potentially lethal intestinal obstruction can occur [10,13-15].

The adult fish tapeworm, genus Diphyllobothrium, is located in the host intestines and is the longest parasite worm of mammals (up to $12 \mathrm{~m}$ long). Infestation occurs after the ingestion of infested raw or undercooked fish. Man, pigs and other carnivores, such as canids, felines, or mustelids can be infested. Contamination with Diphyllobothrium causes abdominal pain, transit disorders and sometimes anemia due to a deficiency in vitamin B12 $[10,14,15]$. The presence of fish tapeworm eggs in the SMV individuals is linked to the consumption of raw or undercooked freshwater fish, with possible consequences on their health. This taxon has been present in the Old World for at least 9,500 years (from the early Neolithic period onwards) [16], but was recovered here for the first time from the Merovingian period.

No parasite eggs were observed in the children's burials (SEP 8584 and SEP 8672). Samples taken from the head and feet served as control samples. In these conditions, the absence of positive results is not surprising. On the other hand, sediments taken from the abdominal cavity and the pelvis area were also negative. Two hypotheses may explain these results: the taphonomy and the age of the individuals. Concerning the question of the taphonomy, it is important to note that pollen grains were observed during the microscopic observation of the samples, and the preservation conditions of these microfossils are considered to be more or less similar than the parasite eggs. Secondly, it is also possible that the children did not carry any intestinal parasites. Their young age, between 5 and 8 months for the first, and between one and one-and-a-half years for the second, could explain this absence of parasites. Indeed, helminth infestations are generally related to the food intake of individuals, or to the contamination of water and food by feces (fecal peril). If the children were still breastfeeding at the time of their death, they would have consumed little or no solid food, which limits the possibilities of infestation by parasites.

Unlike the children, both adults tested positive to the presence of parasites. Ascaris and Trichuris show that they experienced a fecal peril problem, and by extension, the whole Merovingian population of Chartres was probably infested with these 2 very common parasites in Western Europe since 
the Roman period $[11,17]$. On account of the low number of eggs found, we cannot determine the parasite load of the individuals and the incidence of these parasites on the health status of humans. These worms could have been scarce and may not have caused any symptoms. In one adult, the presence of the fish tapeworm indicates the consumption of raw or undercooked fish, and could be related the high social status of the individuals buried in the SMV church. Here again, additional analyses should be performed to acquire a more complete vision of parasite distribution in this privileged population.

The low number of eggs retrieved during the analysis could be explained by the funerary treatment of the bodies, but also by the microbial activity that occurs during the decomposition of corpses, and by taphonomic processes. The sedimentological analyses performed on the sarcophagi revealed the presence of products (balm) used in the embalming process. During the Middle Ages, embalming could be external, by the applying aromatics and plants on the body, but also internal, by extracting the viscera and filling the cavities with drying and odoriferous substances (spices, salt, aromatic herbs, etc.) $[18,19]$. If the presence of some parasite eggs in the samples could point to the presence of the viscera (i.e., only external embalming), the low number of markers could also result from evisceration related to an internal embalming process.

Moreover, except in some scarce cases, such as for the corpses recovered in Nivelles (Belgium), studied by Rácz et al. [20], for which humid conditions favored exceptional preservation, in general, few parasite eggs are retrieved when studying human skeletons. Important microbial activity during decomposition of the bodies could also explain the loss of a large part of paleoparasitological information.

Finally, the presence of eggs of intestinal parasites in some of the control samples taken from under the head and the feet is curious. As no looting damaged or disturbed the sarcophagi, only water infiltration and movement, but also biological processes that occur after the death of the individual (thanatomorphosis) could explain these results. For example, ruptures of the abdominal cavity can occur and contribute to the dispersal of intestinal remains and intestinal parasite remains in the sarcophagi. Similarly, decomposition fluids may also have contributed to the displacement of parasite markers in different parts of the burial [21]

The sarcophagi of SMV church in Chartres constitute an exceptional case study, as up until now, only a few archaeological structures of this type have been studied for ancient parasites.
The Merovingian period is also of interest since data from this period are scarce. The recovered parasites thus supplement our knowledge of parasites for this period. Ascaridiosis and Trichiurosis are 2 common parasitic diseases infecting human populations since the Roman Age. The fish tapeworm has also been documented for several centuries in Western Europe but was identified here for the first time in the Merovingian period $[11,16]$. Its presence could be due to the social status of the individuals buried in the church of Saint-Martin-au-Val.

In addition to the data obtained on the lifestyle and sanitary conditions of ancient populations, our analysis presents additional information on the funeral treatment of the corpses. This information can then be compared to sedimentological analyses, which demonstrated the possible embalming of the bodies. However, the question of embalming methods still remains unresolved.

Excavations are still ongoing in the SMV church and supplementary samples from other sarcophagi should be examined in the future. Other parasite markers, such as paleoantigens and ancient DNA, could also be considered in forthcoming analyses. Finally, in a broader perspective, these positive results should encourage and systematize studies of this type of material.

\section{CONFLICT OF INTEREST}

We have no conflict of interest related to this work.

\section{REFERENCES}

1. Le Bailly M, Araújo A. Past intestinal parasites. Microbiol Spectr 2016; 4.

2. Ruffer MA. Note on the presence of "Bilharzia haematobia" in Egyptian mummies of the twentieth dynasty [1250-1000 B.C.] Br Med J 1910; 16: 65.

3. Szidat L. Uber die Erhaltungsfähigkeit von Helmintheneiern in Vor- und Frühgeschichtlichen Moorleichen. Z Parasitenkd 1944; 13: 265-274 (in Deutsch).

4. Taylor EL. Parasitic helminths in mediaeval remains. Vet Rec 1955; 67: 216-218.

5. Bazin B, Huchin-Godin I, Hérouin S, Portat É. L'église SaintMartin-au-Val. Place Saint-Brice, rue Saint-Martin-au-Val - Chartres (Eure-et-Loir - Centre). Rapport de fouille archéologique. Chartres, France. Ville de Chartres - Service Archéologie. 2015 pp 404 (in French).

6. Bazin B, Guinguéno M, Portat É. L'église Saint-Martin-au-Val. Place Saint-Brice, rue Saint-Martin-au-Val - Chartres (Eure-et-Loir - Centre-Val de Loire). Rapport de fouille archéologique programmée. Chartres, France. Ville de Chartres - Service Archéolo- 
gie. 2017, pp 391 (in French).

7. Bazin B, Portat É. L'église Saint-Martin-au-Val. Place Saint-Brice, rue Saint-Martin-au-Val - Chartres (Eure-et-Loir - Centre-Val de Loire). Rapport intermédiaire de fouilles archéologiques programmées. Chartres, France. Ville de Chartres - Direction de l'Archéologie. 2018, pp 64 (in French).

8. Dufour B, Segard M, Le Bailly M. A First Case of Human Trichuriasis from a Roman Lead Coffin in France. Korean J Parasitol 2016; 54: 625-629.

9. Dufour B, Le Bailly M. Testing new parasite egg extraction methods in paleoparasitology and an attempt at quantification. Int J Paleopathol 2013; 3: 199-203.

10. Ash LR, Orihel TC. Ash \& Orihel's atlas of human parasitology. 5th ed. Chicago, USA. ASCP Press. 2007, pp 540.

11. Dufour B. Synthèse de données et nouvelle contribution à l'étude des parasites de l'époque romaine, et apports méthodologiques de l'extraction des marqueurs au traitement des résultats (dissertation). Besançon, France. University of Bourgogne FrancheComte. 2015, pp 361 (in French).

12. Bouchet F, Guidon N, Dittmar K, Harter S, Ferreira LF, Chaves SM, Reinhard K, Araújo A. Parasite remains in archaeological sites. Mem Inst Oswaldo Cruz 2003; 98 (suppl): 47-52.

13. Kaufmann J. Infections of Domesticated Animals: A Diagnostic Manual. Basel, Switzerland. Birkhauser. 1996, pp 423.
14. Soulsby EJL. Helminths, Arthropods and Protozoa of Domesticates Animals. 7th ed. London, UK. Baillière Tindall. 1982, pp 809.

15. Taylor MA, Coop RL, Wall RL. Veterinary Parasitology. 3rd ed. Oxford, UK. Blackwell Publishing. 2007, pp 900.

16. Le Bailly $\mathrm{M}$, Bouchet F. Diphyllobothrium in the past: review and new records. Int J Paleopathol 2013; 3: 182-187.

17. Mitchell PD. Human parasites in the Roman World: health consequences of conquering an empire. Parasitology 2017; 144: 4858.

18. Charlier P. L'embaumement: rituel et symbole de pouvoir en Occident. Histoire des Sciences Médicales 2015; 49: 99-104 (in French).

19. Georges P. L'embaumement médiéval des nantis. Dossier Pour la Science 2006; 50: 98-101 (in French).

20. Rácz SE, De Araújo EP, Jensen E, Mostek C, Morrow JJ, Van Hove ML, Bianucci R, Willems D, Heller F, Araújo A, Reinhard KJ. Parasitology in an archaeological context: analysis of medieval burials in Nivelles, Belgium. J Archaeol Sci 2015; 53: 304-315.

21. Charlier P, Durigon M. L'apport de la médecine légale à la paléopathologie. In Charlier P ed, Ostéo-archéologie et techniques médico-légales: tendances et perspectives: pour un "Manuel pratique de paléopathologie humaine". Paris, France. De Boccard. 2008, pp 55-69 (in French). 
